\title{
Climate Warming in the Spanish Mediterranean: Its Magnitude and Nature
}

\author{
J. Quereda ${ }^{1}$, E. Montón ${ }^{1}$ and V. Quereda ${ }^{1}$ \\ ${ }^{1}$ Climate Laboratory, Universitat Jaume I
}

Received: 10-V-2019 - Accepted: 26-XI-2019 - Original version

Correspondence to: quereda@uji.es

\begin{abstract}
This piece of research completes the line of work on the thermal evolution of the Mediterranean region initiated in the National Plan on Climate Change. The study was undertaken to analyse the active regional thermal series over the 1950-1996 period, rigorously treated by the SNHT (Standard Normal Homogeneity Test) method. This research concluded that the evolution of the mean annual temperatures recorded in the major historical network of Spanish Mediterranean observatories exhibits a significant warming trend. However, analysis of the non-climatic processes, such as the urban effect and weather station relocations, allowed us to conclude (in a study published in 2004) that the assumption of temperature stability in the Spanish Mediterranean should therefore not be rejected. Conclusions that were partially verified in 2016, in particular of the true the urban effect, about the period (1950-2013). The results obtained showed that this magnitude could account for between 70 and $80 \%$ of the recorded warming trend in Western Mediterranean cities.

In this context, twenty years after the end of the Plan Nacional del Clima, it would be wise to revisit, in 2019, the validity of the conclusions that the regional climate offered. This piece of research aims to assess the true magnitude of the climate warming recorded in the Spanish Mediterranean region. The evaluation is based on the records of 23 observatories belonging to the Spanish regional network of the State Meteorological Agency (AEMET), with complete series covering the 1950-2018 period, processed by the SNHT. The verification is further based on three new analyses. The first involves the analysis of the thermal evolution (1906-1925 and 1991-2018) at the observatory on the Columbretes Islands (28 miles off the coast of Castellon). The island climate series entails in-depth revision of the conclusions and trends set out in our previous studies. The second piece of research involves the magnitude of the Urban Heat Island (UHI, 2001-2018) using temperature records from seven weather stations located in the CastellonAlmassora urban area. The third piece of research was based on the analysis of a trend value that has stabilized since 2010, simultaneously to the decline of the population and the descent of total energy consumption. Therefore, this piece of work verifies the importance of the UHI and establishes the magnitude of the real t regional warming. The study suggests that the real value of climate warming in the Spanish Mediterranean region may be estimated at between $1^{\circ} \mathrm{C}$ and $1.1^{\circ} \mathrm{C}$ in the period from 1950 to 2018.
\end{abstract}

Key words: Temperature, urban effect, heat island, coastal area, Columbretes Islands, homogeneity, SNHT, climate change 


\section{Introduction}

Climate change is the main environmental problem that society will face over the next twenty-five or fifty years. This atmospheric process emerges as one of the major current scientific challenges. The challenge is urgent, in view of the great climate anomalies recorded in recent years, particularly regarding rising temperatures. The fifteen warmest years exhibiting a mean annual temperature exceeding $19^{\circ} \mathrm{C}$ occurred between 1994 and 2018 in the coastal area of the Spanish Mediterranean (the region in question). This study was undertaken to examine the actual magnitude and nature of these trends, this being a fundamental objective with regard to current environment mitigation policies (OECC, 2006).

In this context, the study of climate change in the Mediterranean region has become of great importance in view of the predictions developed by climate change models for the Mediterranean region. The latest IPCC reports (Solomon et al., 2007; Stocker et al., 2013) indicate that this will be the most vulnerable European region regarding the effects of climate change. The vulnerability stems from a predicted regional thermal increase of 1.5 to $3^{\circ} \mathrm{C}$ during the 21 st century, occurring at the same time as a decrease in water resources, basically linked to the intensification of the hydrological cycle. The resulting desertification process would then embody the greatest environmental issue for this region.

The axis of these important atmospheric and environmental processes is the elevation of temperature. An elevation, the magnitude and nature of which, in the Spanish Mediterranean region, constitute the scientific objective of this work. An objective that requires rigorous analysis, both in terms of data quality control and in the elimination of nonclimate effects. Thus, though studies have striven to control data quality, the field at issue continues to exhibit many uncertainties. Oscillations of half a degree or even more require close scrutiny. Such variations might be caused just by relocating the shelter or the weather stations. Appropriate analysis of temperature data records is, therefore, not a simple matter as it also requires accounting for the effect of nonclimatic processes such as city growth around observatories and the relocation of weather stations. The most striking, extremely subtle such impact is clearly the UHI effect.

Although the UHI effect seems incontrovertible, its role is widely debated. Thus, for example, though the IPCC scientific protocols recognize the urban microclimate effect, this is only deemed to impact the local temperature trend and to be practically negligible on a regional or global scale. In addition, the phenomenon may be offset by the ocean's influence and, therefore, the overall impact of the UHI effect on global warming may tend to zero (Solomon et al., 2007). Therefore, though urban heating may be deemed of local significance, evidence is lacking as to its effect on global temperatures (Solomon et al., 2007; Trenberth et al., 2007). The debate is still open, as shown by studies analysing the influence of climate change on the UHI (Sachindra et al., 2016; Chapman et al., 2017).
Nevertheless, scientific assumptions concerning the UHI effect are being re-examined, as evidenced by the IPCC Fifth Assessment Report (Stocker et al., 2013). Similarly, studies in progress in China and in industrial regions elsewhere have further highlighted these considerations. The comparison of urban and rural regional temperatures has led a number of researchers to suggest that the UHI effect could account for $40-80 \%$ of the temperature trend noted in recent decades (Ren et al., 2008; Yan et al., 2010). In the US, McKitrick and Michaels (2007) similarly concluded that local land surface modifications might have given rise to half the warming trend noted from 1980 to 2002. Attempts have been undertaken to balance or lower these magnitudes by satellite radiation and reanalysis measurements (Parker, 2011; Jones et al., 2012). The resulting decreases have not, however, impeded a significant review of the conclusions drawn in the IPCC's fourth report (Solomon et al., 2007). According to Efthymiadis and Jones (2010), the UHI effect would thus only account for $0.02^{\circ} \mathrm{C}$ per decade and up to $15 \%$ of global warming in the period from 1951 to 2009. Other studies similarly report a greater impact of the UHI effect as climate change develops (Sachindra et al., 2016).

In Spanish climatology, this process has been recognized in large cities such as Madrid, Barcelona, Córdoba, and Granada (López Gómez et al., 1991; Acero et al., 2014). The interest of this process has determined that the PNACC (Spanish National Plan on Climate Change) in its introduction, noted: "to plan an adaptation for a warming horizon of $2^{\circ} \mathrm{C}$ is not the same as to plan one for a warming horizon of $4^{\circ} \mathrm{C}$ " (OECC, 2006).

In view of these uncertainties, a close examination of the data quality of the temperature series and a specific analysis of the UHI effect is needed, a process that might be biasing our understanding of global temperature development (Lee, 1992; Quereda et al., 2004).

\section{Materials and methods}

\subsection{The analysis of the temperature series: method- ology and techniques}

The methodology used to achieve the proposed objectives involves analysis of the thermal records of 23 regional climate series, one of them an island (Columbretes). This analysis constitutes the scientific basis for accurately establishing the regional climate trend between 1950 and 2018 . The results enabled the true magnitude of the warming to be verified, as well as it matching climate change model projections.

The verification was conducted on a regional network of 23 AEMET (State Meteorology Agency) observatories. All these observatories, except that of the Columbretes Islands, have 69-year series and cover the 1950-2018 period in the Spanish Mediterranean region. This territorial delimitation provides a thermal network with great spatial cohesion between urban and rural stations. At the same time, the 


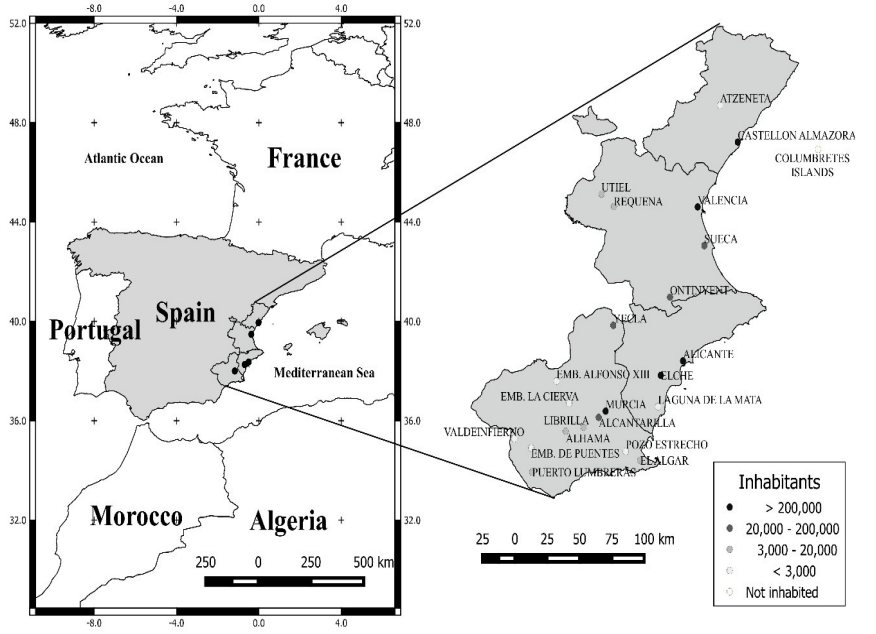

Figure 1: Map of the regional network of observatories with complete temperature series over the 1950-2018 period. Source: AEMET and own graph.

northern observatories in the studied region (Fig. 1) provide a very consistent climatic framework with the experimental processes conducted on the urban heat island (UHI) in the Castellón area (2001-2018).

The basic technique in this analysis was the homogeneity control of the climate time series at all regional observatories. It was thus sought to establish the true magnitude of the heterogeneities stemming from non-climatic or urban effects and the environment or other variations. The control technique used was the SNHT of the Alexandersson method (Alexandersson, 1986; Moberg and Alexandersson, 1997). Using the best statistical innovations, this method allows for a satisfactory solution to the problem of the treatment of climate time series. Using the Alexandersson method, a series is defined as homogeneous with regard to a synchronic reference series if the differences between simultaneous observations constitute a series of random numbers. This requires defining a reference series. This series must display homogeneous characters and a high correlation with the studied series. However, although for each observatory to be tested, another nearby observatory exhibiting a good correlation with the studied series can readily be found, it becomes difficult, in contrast, to characterize the quality of each series. This makes it necessary to calculate a mean reference series from the different series, which blurs the heterogeneities.

For each observatory a specific reference was obtained from the calculation of the weighted average of the squares of the correlation coefficients. Each series thus has its specific corresponding weight in the configuration of the reference series. The differences between the actual temperatures and the reference ones, once normalized, are the components of these series. The test determines significant changes with respect to the mean. For each period (month or year), a comparison is made between the determined value and the critical value for a given confidence. Heterogeneity is established

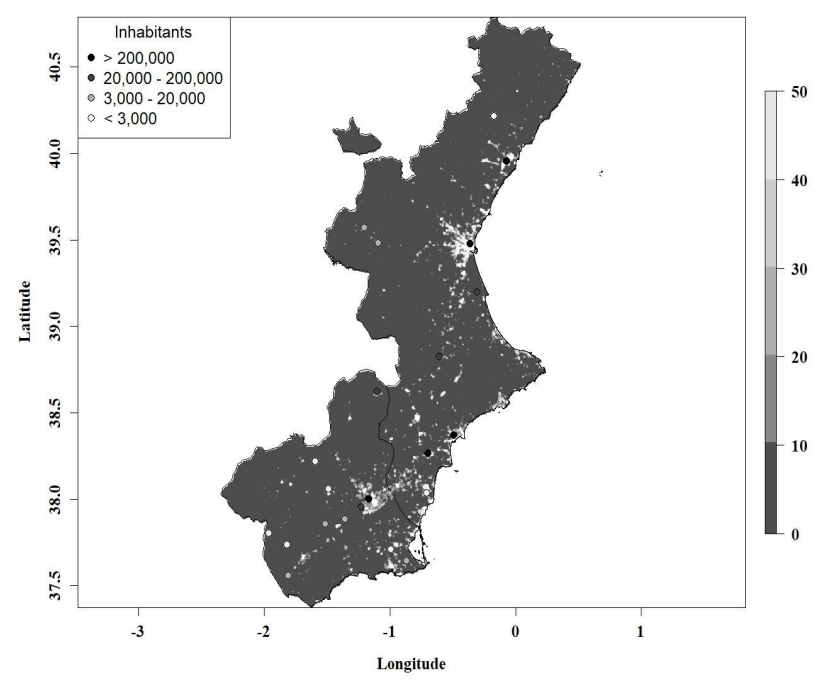

Figure 2: Map of average radiance (expressed in $W s r^{-1} m^{-2}$ ) using night-time lights (2018) from VIIRS. Source: Earth Observation Group (EOG) at NOAA/NCEI (Mills et al., 2013) and own graph.

when the critical value is exceeded. The most likely data for a homogeneity break corresponds to the maximum value of the test.

However, although the SNHT homogenization method is one of the most widely used methods in the treatment of climate time series (Aguilar et al., 2003; Khaliq and Ouarda, 2007), it nonetheless contains a weakness (Quereda et al., 2016). This weakness lies in the method. The method obtains averages of series, regardless of their homogeneity, to attenuate the effects of the breaks in inhomogeneous series, which may unfortunately be numerous. Although these homogeneity breaks are usually detected in the series being tested, it must be taken into consideration that the deduced correction factors of the series of differences may be biased. In effect, the trends of the corrected series and of the reference series are usually smoothed when a series is corrected from the reference series. Thus, the results may be distorted when the quality of the reference series is uncertain, which is, a priori, the case. Two precautions were therefore taken. The first consisted of eliminating the clearly inhomogeneous series: that is, when the correlation coefficient was less than 0.7 below the reference calculations. The second precaution involved comparing the test results with those obtained in the records of the experimental work plan on the UHI of the Castellón area and in the thermal records of the Columbretes Islands.

In order to complete the study, the different urbanization conditions of the observatories were identified. For this, firstly, the average radiance composite images using night-time data from the Visible Infrared Imaging Radiometer Suite (VIIRS) Day/Night Band (DNB) were examined, provided by the Earth Observations Group (EOG) at NOAA/NCEI (Fig. 2). Secondly, analysis of the urban 


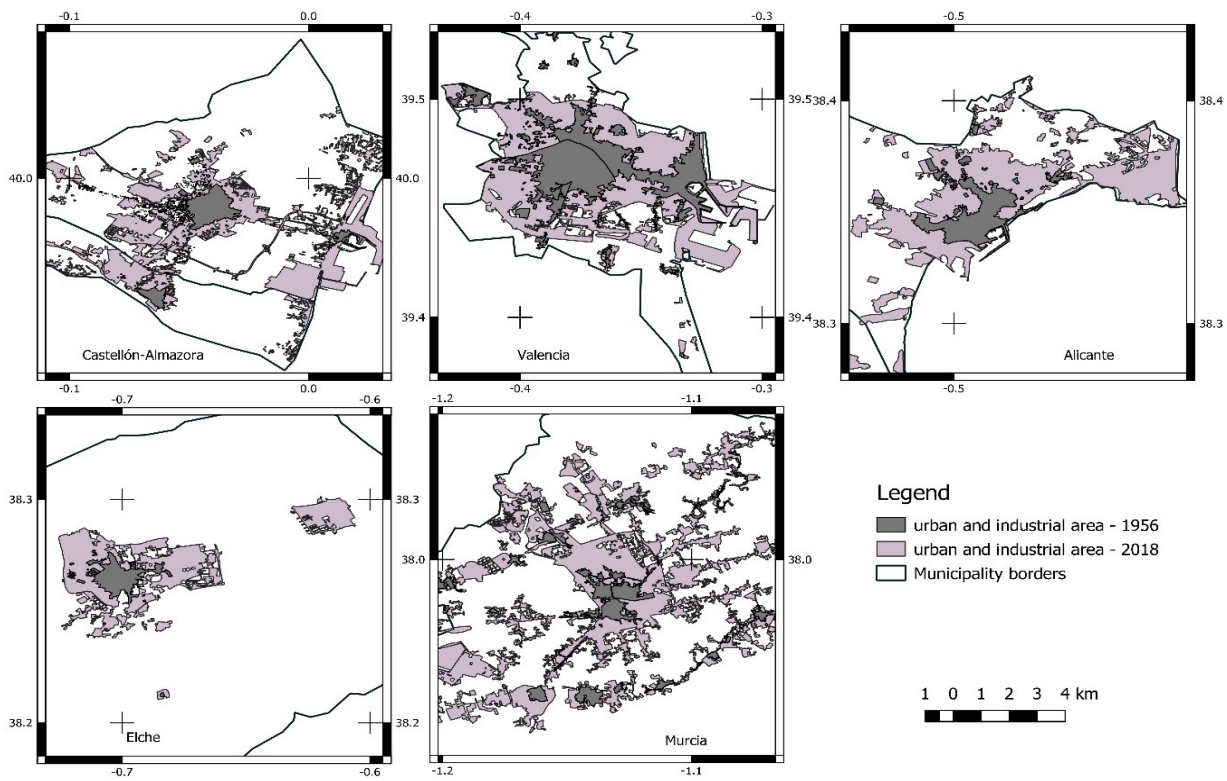

Figure 3: Maps showing the increasing urbanization in metropolitan areas around the five urban observatories. Source: CNIG/CND (http://centrodedescargas.cnig.es/CentroDescargas/index.jsp), ICV/IDEV (http://www.idev.gva.es/va/inicio) and own graph.

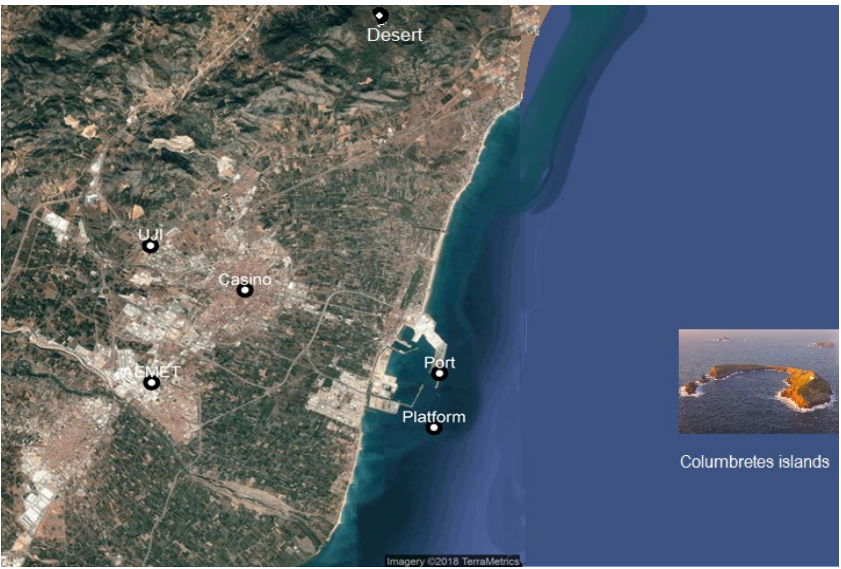

Figure 4: Network of stations in the Castellón urban area used in this study: University marine station on the BP oil rig (Platform), land stations of Universitat Jaume I (UJI Casino, Port, Desert), Castellón-Almassora Observatory (AEMET) and Columbretes Islands, (28 miles off the coast of Castellón, AEMET).

growth at the main observatories was performed in more detail. This analysis was conducted by using a geographic information system (GIS), comparing the orthophotos of the American flight of 1956 with the most recent images obtained from the National Geographic Institute and the Valencia Cartography Institute (Fig. 3).

\subsection{The experimental setting: a specific analysis of} the UHI effect

The magnitude of the UHI on the Spanish Mediterranean region was experimentally analysed (2001-2018) using temperature records from seven weather stations located in the Castellón-Almassora urban area (Fig. 4), a low plain where there are six of the seven experimental meteorological network observatories. This meteorological network appears dominated, in height, by the Observatory of the Desert $(712 \mathrm{~m})$, and by insulation, by the seventh observatory in the Columbretes Islands, 28 miles off the coast of CastellónAlmassora. This urban area of Castellón-Almassora city's population has grown notably in recent years. In 1970, the urban area had 106,000 inhabitants, whereas in 2010 it had almost 181,000 inhabitants, although in 2018 it only had 170,000 inhabitants.

\section{Results}

\subsection{Regional temperature evolution}

All series were processed applying the methodology described in Sect. 2. The results of the analytical methodology displayed a significant climate warming trend in the Spanish Mediterranean region. The secular mean value of this trend at the five first-order observatories studied (Murcia, Elche, Alicante, Valencia, and Castellón) was notable: $1.6^{\circ} \mathrm{C}$ in the $1950-2018$ period. This warming may be considered dramatic, since it has only been recorded since 1980: the trend, which had remained static from 1950 to 1980 , then acquired an extraordinary magnitude of a $4^{\circ} \mathrm{C}$ secular trend (Fig. 5). This trend, in the 1950-2018 period, is statistically significant. The t-Student test provides a high significance level $(<.0001)$.

A trend value that has stabilized since 2006, simultaneously to the decline of the population and the descent of total energy consumption and emissions in the Spanish Mediterranean (Fig. 6). The observation of this phenomenon, a stagnation in global warming often termed the global warming hiatus, has caused a fierce debate 


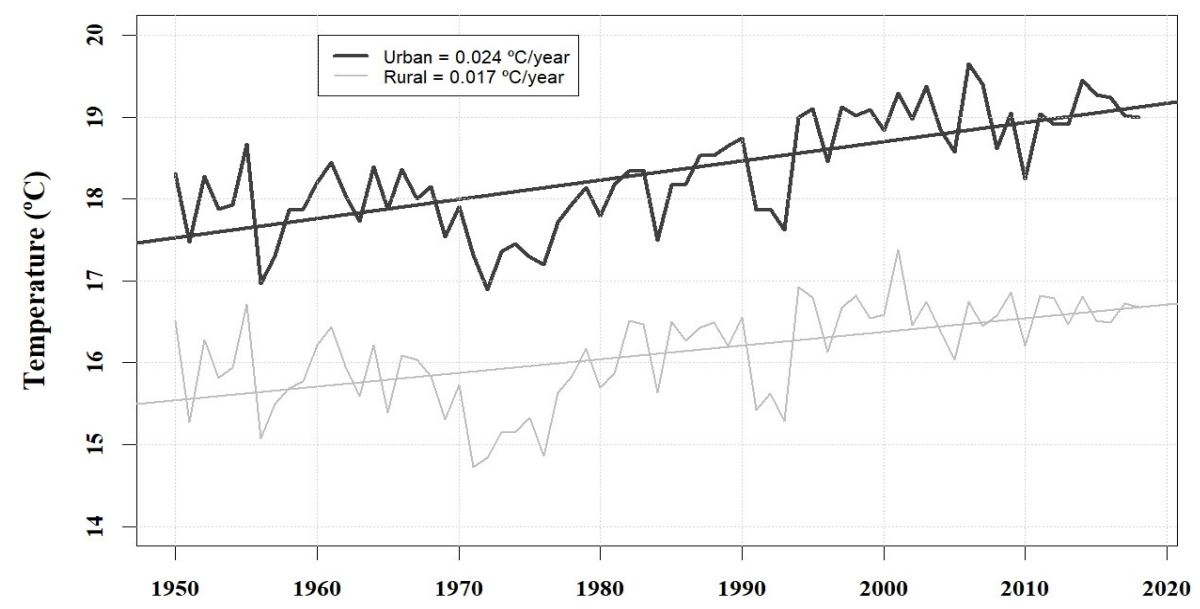

Figure 5: Evolution of mean annual temperature (1950-2018) in the Spanish Mediterranean region. Average of the five "urban" observatories, located in cities of over 200,000 inhabitants (Murcia, Elche, Valencia, Alicante, and Castellón), compared with the average of the 17 "rural" observatories, located in less densely populated areas. Source: AEMET. Own graph.

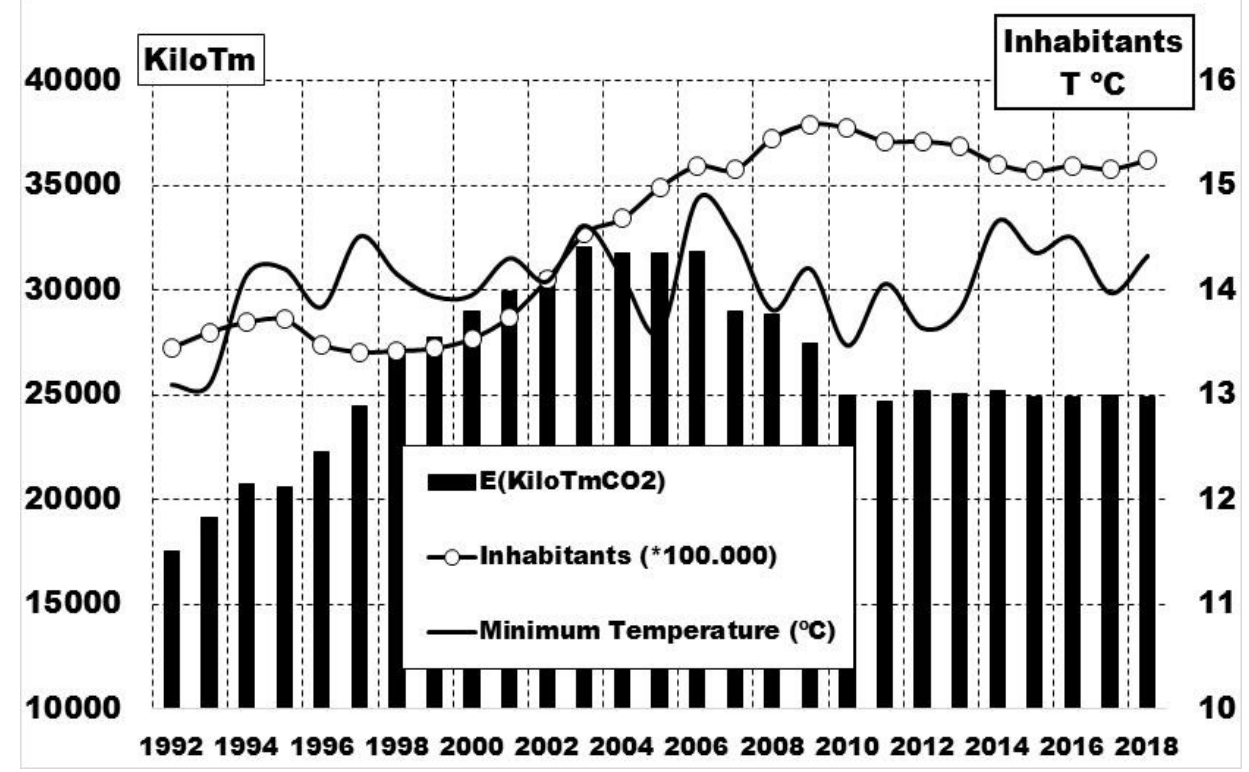

Figure 6: The decline of the population (Inhabitants), the descent of total emissions (E) and the stagnation of the average temperature in the Spanish Mediterranean (TM). Sources: SEI, Ministry of Ecological Transition and INE, (National Institute of Statistics).

on its existence and formation (Gonzalez-Hidalgo et al., 2016; Li et al., 2015; Roberts et al., 2015). The IPCC's Fifth Assessment Report also clearly stated that the global warming trend slowed significantly in the 1998-2012 period compared with the previous 30-60 years. The coincidence with the decline in GHG emissions, seems to confirm that human influence is dominant in long-term warming.

However, rigorous analysis of this complex and contrasted trend warming raises certain doubts as to its nature and magnitude. The sharp increase since 1980, of both the different magnitudes in warming at the urban observatories ( $>200,000$ inhabitants) and at the more rural ones, and the different behaviours of maximum and minimum temperatures raise doubts about the (natural or anthropogenic) nature and magnitude of the warming. This difference and development are again evidenced in the maximum and minimum temperatures (Fig. 7). These processes therefore need to be studied.

Consequently, the doubts raised as to the true value of the warming trends and magnitudes require analysis, since part of this temperature rise may be due to the urbanization effect, increasing progressively as meteorological observatories have become enveloped by urban growth. This process may explain the fact that most of the warming has occurred in the 


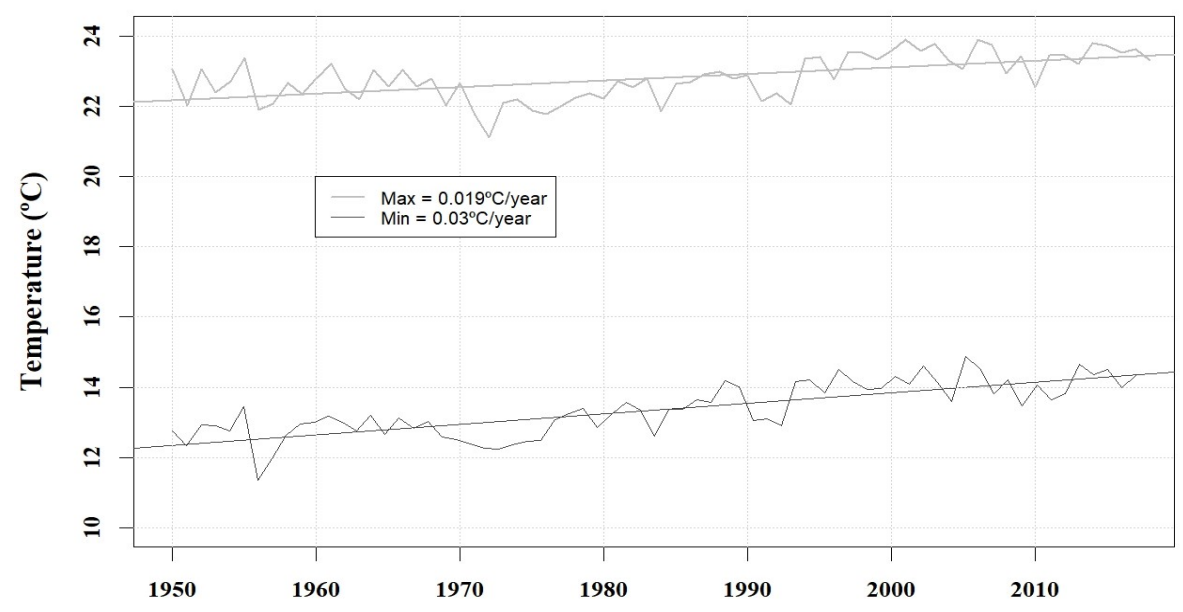

Figure 7: Evolution and trend of annual maximum and minimum temperatures in the network of first-order observatories (Murcia, Elche, Alicante, Valencia, and Castellón) (1950-2018). Source: AEMET. Own graph.

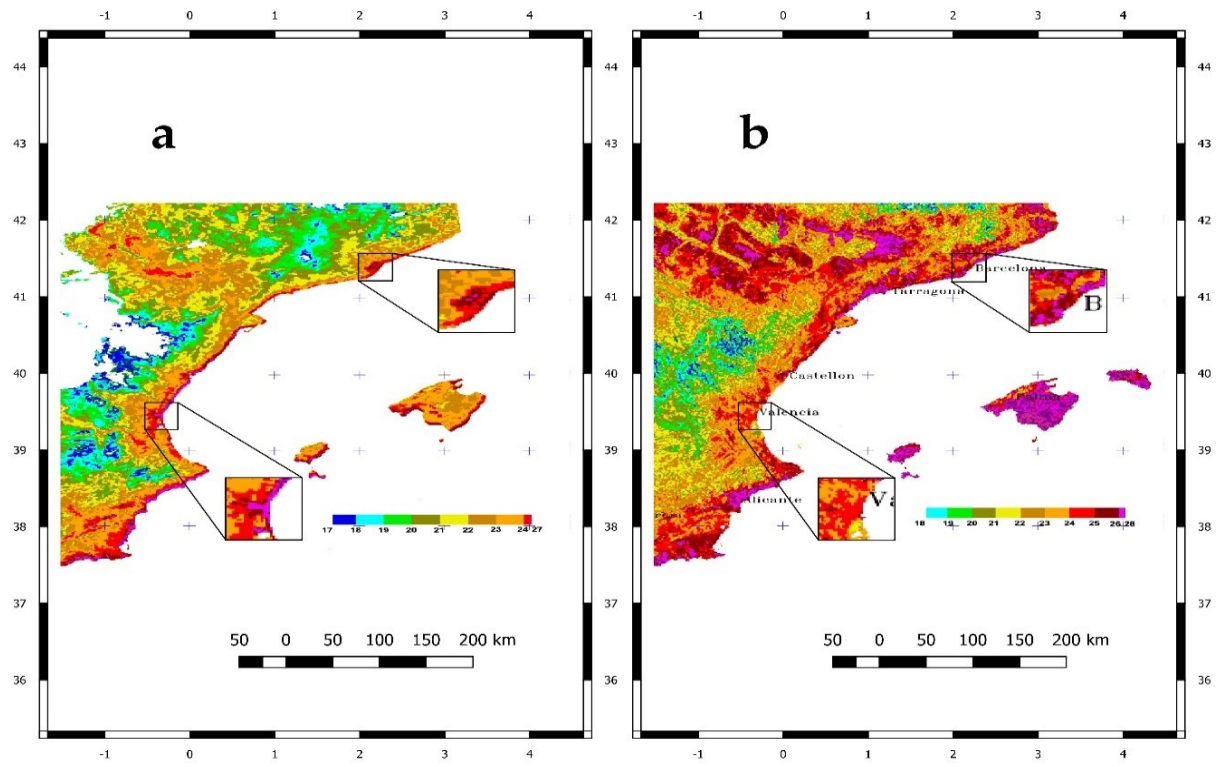

Figure 8: NOAA-HRPT image, taken on (a) 5 August 2003 21:36 and (b) 6 August 2003 07:04. Climatology Laboratory, Universitat Jaume I. The thermographs (Air temperatures, ${ }^{\circ} \mathrm{C}$ ) obtained after implementing the atmospheric correction, show the thermal effect of coastal conurbation. The imagery used in this study comes from the NOAA-KLM series, AVHRR/3 remote sensor.

minimum temperatures, with a value of $2.1^{\circ} \mathrm{C}$ between 1950 and 2018. The evolution of the maximum temperatures, with a rise of just $1.2^{\circ} \mathrm{C}$ in the same period, would hardly have contributed to halve the recorded warming in the average temperatures. The statistical significance of this trend has been verified by the probability distribution $t$ (from Student). The t-Student test gives a correlation value close to 0.55 and a correlation probability of $<.0001$, indicative of high significance between the two variables.

Although these results differ from those obtained in some studies (Brunet et al., 2007), the greater increase in minimum temperatures for the Mediterranean coastal areas has also been observed in other studies (Miró et al., 2006; Acero et al., 2014), also possibly caused by urbanization (Gonzalez-Hidalgo et al., 2015; González Hidalgo et al., 2016). This effect has also been clearly evidenced in satellite thermographs (Fig. 8).

\subsection{Results of the UHI effect}

The meteorological series analysed here cover the 2001-2018 period. In this period, while the AEMET and Columbretes Islands observatories were operating, five other automatic meteorological stations of the University Network 
Table 1: Secular evolution of Mediterranean temperatures

\begin{tabular}{|l|c|c|c|}
\hline & Temperature $\left({ }^{\circ} \mathrm{C}\right)$ & Temperature $\left({ }^{\circ} \mathrm{C}\right)$ & Temperature $\left({ }^{\circ} \mathrm{C}\right)$ \\
\hline Period/Station & Island $($ Columbretes $)$ & AEMET $($ Castellón) & AEMET (Valencia) \\
\hline $1906-1925$ & 17.1 & 16.1 & 16.5 \\
\hline $1992-2018$ & 18.2 & 18.4 & 18.8 \\
\hline Difference & 1.1 & 2.3 & 2.3 \\
\hline
\end{tabular}

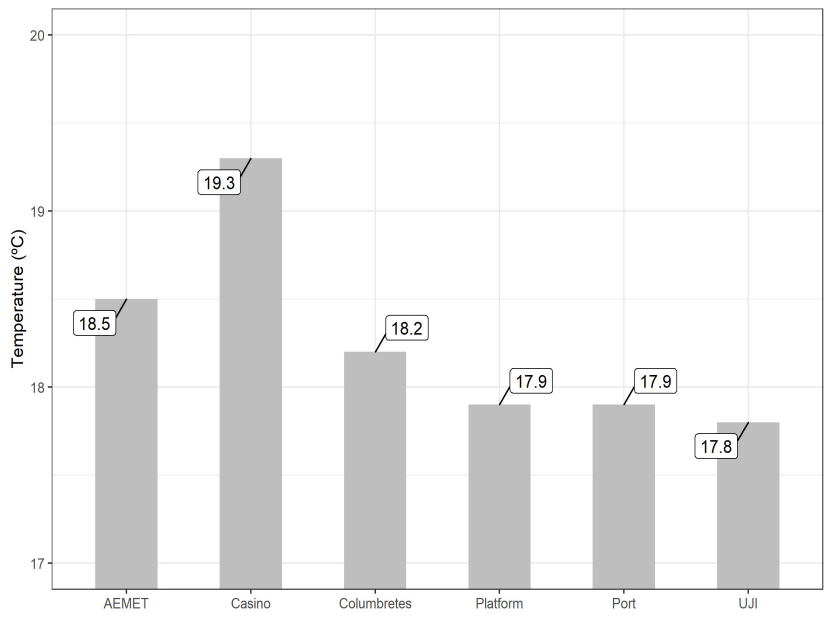

Figure 9: The values of the mean annual temperatures at the different observatories (2001-2018) show the possible extent of the UHI. Source: Universitat Jaume I, AEMET. Own graph.

(UJI, Casino, Port, Platform and Desert) were started up. These stations, with records at ten-minute intervals, were constantly controlled and calibrated. Despite the brevity of the period, this analysis was therefore quite rigorous in all records and may be deemed a valuable experience in the study of the effect of urban heat.

The average annual temperature of the six observatories analysed (Fig. 9) exhibited a significant difference between the value of the Casino station, in the city centre, $19.3^{\circ} \mathrm{C}$, and the AEMET observatory (only $2 \mathrm{~km}$ from Castellón city centre), $18.5^{\circ} \mathrm{C}$, and the value of the other meteorological stations located on the urban outskirts (UJI, $17.8^{\circ} \mathrm{C}$; Port, $17.9^{\circ} \mathrm{C}$, Platform, $17,9^{\circ} \mathrm{C}$ ). Thus, assuming that the observatories on the Castellón city outskirts were unaffected by the influence of urban heat, the value of the UHI with respect to the urban centre (Casino) may be estimated to swing between 1.4 and $1.5^{\circ} \mathrm{C}$. and 0.6 and $0.7^{\circ} \mathrm{C}$ with respect to the AEMET observatory.

The urban effect is highlighted especially when comparing the annual average temperature recorded (2001-2018) at the Columbretes Islands, $18.2^{\circ} \mathrm{C}$, with the average annual temperature recorded at the Casino station, $19.3^{\circ} \mathrm{C}$. As a result, the magnitude of the UHI may be estimated at $1.1^{\circ} \mathrm{C}$. This is a high value, since the Columbretes station, located $63 \mathrm{~m}$ above the sea-land interface, has a thermal regime governed by the sea's thermostatic effect $\left(19^{\circ} \mathrm{C}\right.$ is the mean annual temperature of the sea surface, measured at the Platform). The sea's thermostatic role is a determining factor, as shown by the mean minimum temperature, $15.7^{\circ} \mathrm{C}$, and the

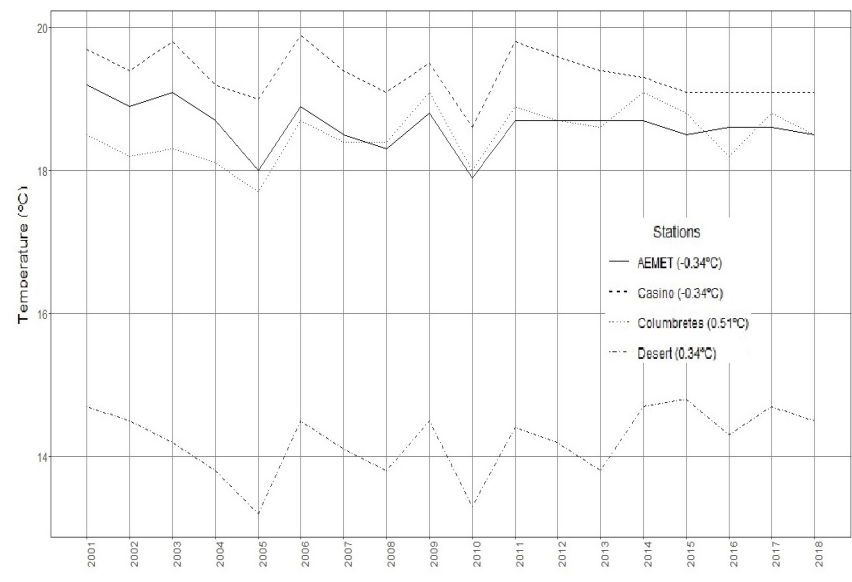

Figure 10: Evolution of mean annual temperature (2001-2018) in the experimental Meteorological network.

mean maximum temperature, $20.7^{\circ} \mathrm{C}$, on the Columbretes Islands.

Consequently, the magnitude of the UHI would be close to $1.1^{\circ} \mathrm{C}$. However, the magnitude of the UHI is clearly higher with respect to the urban centre. The basis of this evaluation lies in the comparison of the warming recorded in the Columbretes Islands with the historical stations of AEMET (Castellón and Valencia). The actual elevation of temperature over the last century in the Columbretes Islands, with no UHI effect, has been $1.1^{\circ} \mathrm{C}$, whereas in the continental stations of AEMET, it has been $2.3^{\circ} \mathrm{C}$ (Table 1). Consequently, the UHI represents a $52 \%$ of the heating recorded in the continental weather station of AEMET (Castellón), in front of the Columbretes Islands. The t-Student provides a value close to 0.6 and a high significance level $(<.0001)$ that indicates the high relation between variables of AEMET (Castellón) and ISLAND (Columbretes).

These values of real climate warming are endorsed by the temperature records on the Columbretes Islands in the 1905-1926 period (Wrobel, 1940) and the mean value of the recent 1991-2018 period (AEMET). The records at the beginning of the century correspond to the observations of the lighthouse keeper who lived with his family on the islands. The current records correspond to the automated AEMET observations since 1992. The records indicate that there is a difference of $+1.1^{\circ} \mathrm{C}$ between the mean temperature of the period $1906-1925$, which is $17.1^{\circ} \mathrm{C}$, and the mean value of the $1991-2018$ period, $18.2^{\circ} \mathrm{C}$. The increase is even lower if one goes back to the mean values of the same periods in the NOAA ERSST database (Huang et al., 2017), at the grid point closest to the islands, namely $0.89^{\circ} \mathrm{C}$. It may be noted 


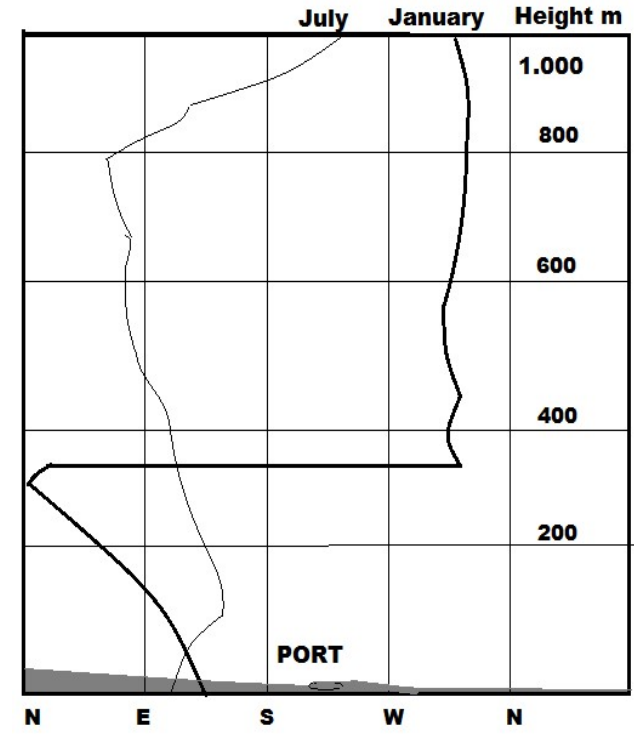

Figure 11: Average of atmospheric sounding in the months of January and July at 12:00, Tethered balloon, Port of Castellón. Air CIEMAT-UJI.

that the old measurement technique, half of the sum of the maximum and minimum temperature values, exhibited an error of less than $0.1^{\circ} \mathrm{C}$ in the platform marine records.

All these records are conformed to the evolution of temperatures (2001-2018) in the experimental Meteorological network. The Observatory of the Columbretes Islands has shown an increase in temperature of $0.5^{\circ} \mathrm{C}$ and that of Desert $(712 \mathrm{~m}), 0.4^{\circ} \mathrm{C}$. On the contrary, the records of AEMET and CASINO have shown a negative trend of $-0.3^{\circ} \mathrm{C}$, simultaneously to the demographic decline of the area that has lost about 10,000 inhabitants in the last ten years (Fig. 10).

The atmospheric sounding of the wind direction through a tethered balloon shows that, especially in winter, the air cell affected by the UHI does not reach the altitude of the Observatory of the Desert (712 m) (Fig. 11). This vertical structure of the regional low atmosphere could explain the different trend of temperatures in the Desert and Columbretes observatories, unaffected by the recent hiatus in the urban observatories of Aemet and Casino.

\section{Conclusions}

This study rounds off a series of research into temperature development and thermal evolution, originated in the Spanish National Plan on Climate Change in 1997. In this context, twenty years later, this study focuses on three key objectives in the Spanish Mediterranean region (Murcia and Valencia Regions): the establishment of the temperature trends recorded between 1950 and 2018; the analysis of the non-climatic causes involved, in particular, the analysis of the true cause of these climate warming trends in view of their possible link to the urban effect; and, finally, assessment of the true magnitude of the Spanish Mediterranean regional climate warming.
The results of the analytical methodology evidenced a significant climate warming in the Spanish Mediterranean region. The secular mean value of this difference covering the 1950-2018 period, at the five first-order observatories studied (Murcia, Elche, Alicante, Valencia, and Castellón) is noticeable: $1.6^{\circ} \mathrm{C}$ for the $1950-2018$ period. This significant warming value, however, fails to dispel certain doubts regarding its nature and magnitude. The results include both the sharp temperature increase since 1980 and the different value of this trend at the "urban" observatories (located in cities with over 200,000 inhabitants) compared with that at the more "rural" observatories, located in less densely populated areas.

This poses a key question in the regional risingtemperature process. Are urban areas contributing to the observed warming trend? The answer to be drawn from the present analysis is fully affirmative. The basis of this answer lies in the comparison of the warming recorded in the Columbretes Islands with the historical stations of AEMET (Castellón and Valencia). The actual elevation of temperature over the last century in the Columbretes Islands, with no UHI effect, has been $1.1^{\circ} \mathrm{C}$, whereas in the continental stations of AEMET, it has been $2.3^{\circ} \mathrm{C}$. Consequently, as a result, the value of UHI could be equivalent to $52 \%$ of the heating recorded in the continental weather station of AEMET (Castellón), in front of the Columbretes Islands. These results, obtained in the Spanish Mediterranean region, allow the great magnitude that the UHI may be acquiring at observatories currently recording their data within urban areas to be evaluated. A conclusion reinforced by the impact of emission reduction during the recent stagnation or hiatus in regional warming.

\section{References}

Acero, F., García, J. A., Gallego, M. C., Parey, S., and DacunhaCastelle, D., 2014: Trends in summer extreme temperatures over the Iberian Peninsula using nonurban station data, J. Geophys. Res., 119, 39-53, doi:10.1002/2013JD020590.

Aguilar, E., Auer, I., Brunet, M., Peterson, T., and Wieringa, J., 2003: Guidelines on climate metadata and homogenization. world climate programme data and monitoring wcdmp-no. 53, wmo-td no. 1186, WMO, 55.

Alexandersson, H., 1986: A homogeneity test applied to precipitation data, Int. J. Climatol., 6, 661-675, doi:10.1002/joc.3370060607.

Brunet, M., Jones, P. D., Sigró, J., Saladié, O., Aguilar, E., Moberg, A., Della-Marta, P. M., Lister, D., Walther, A., and López, D., 2007: Temporal and spatial temperature variability and change over Spain during 1850-2005, J. Geophys. Res., 112, doi:10.1029/2006JD008249.

Chapman, S., Watson, J. E., Salazar, A., Thatcher, M., and McAlpine, C. A., 2017: The impact of urbanization and climate change on urban temperatures: a systematic review, Landsc. Ecol., 32, 1921-1935, doi:10.1007/s10980-017-0561-4.

Efthymiadis, D. A. and Jones, P. D., 2010: Assessment of maximum possible urbanization influences on land temperature data by 
comparison of land and marine data around coasts, Atmosphere, 1, 51-61, doi:10.3390/atmos1010051.

Gonzalez-Hidalgo, J. C., Peña-Angulo, D., Brunetti, M., and Cortesi, N., 2015: MOTEDAS: a new monthly temperature database for mainland Spain and the trend in temperature (1951-2010), Int. J. Climatol., 35, 4444-4463, doi:10.1002/joc.4298.

González Hidalgo, J. C., Peña, D., Salinas, C., Jiménez Castañeda, A., and Brunetti, M., 2016: Variaciones recientes de las temperaturas en España: el efecto del período elegido en las tendencias de las series estacionales de promedios de máximas y mínimas, doi:10.14198/XCongresoAECAlicante2016-44.

Gonzalez-Hidalgo, J. C., Peña-Angulo, D., Brunetti, M., and Cortesi, N., 2016: Recent trend in temperature evolution in Spanish mainland (1951-2010): from warming to hiatus, Int. J. Climatol., 36, 2405-2416, doi:10.1002/joc.4519.

Huang, B., Thorne, P., Banzon, V., Boyer, T., Chepurin, G., Lawrimore, J., Menne, M., Smith, T., Vose, R., and Zhang, H., 2017: NOAA Extended Reconstructed Sea Surface Temperature (ERSST), Information NNCfE, 5.

Jones, P., Lister, D., Osborn, T., Harpham, C., Salmon, M., and Morice, C., 2012: Hemispheric and large-scale land-surface air temperature variations: An extensive revision and an update to 2010, J. Geophys. Res., 117, doi:10.1029/2011JD017139.

Khaliq, M. and Ouarda, T., 2007: On the critical values of the standard normal homogeneity test (SNHT), Int. J. Climatol., 27, 681-687, doi:10.1002/joc.1438.

Lee, D. O., 1992: Urban warming?-An analysis of recent trends in London's heat island, Weather, 47, 50-56.

Li, Q., Yang, S., Xu, W., Wang, X. L., Jones, P., Parker, D., Zhou, L., Feng, Y., and Gao, Y., 2015: China experiencing the recent warming hiatus, Geophys. Res. Lett., 42, 889-898, doi:10.1002/2014GL062773.

López Gómez, A., López Gómez, J., Fernández García, F., and Arroyo Ilera, F., 1991: El clima urbano de Madrid: la isla de calor, Centro de Investigaciones sobre la Economía, la Sociedad y el Medio, CSIC, Madrid.

McKitrick, R. R. and Michaels, P. J., 2007: Quantifying the influence of anthropogenic surface processes and inhomogeneities on gridded global climate data, J. Geophys. Res., 112, doi:10.1029/2007JD008465.

Mills, S., Weiss, S., and Liang, C., 2013: VIIRS day/night band (DNB) stray light characterization and correction, in: Earth Observing Systems XVIII, vol. 8866, p. 88661P, International Society for Optics and Photonics, doi:10.1117/12.2023107.

Miró, J., Estrela, M., and Millán, M., 2006: Summer temperature trends in a Mediterranean area (Valencia region), Int. J. Climatol., 26, 1051-1073, doi:10.1002/joc.1297.

Moberg, A. and Alexandersson, H., 1997: Homogenization of Swedish temperature data. Part II: Homogenized gridded air temperature compared with a subset of global gridded air temperature since 1861, Int. J. Climatol., 17, 35-54, doi:10.1002/(SICI)1097-0088(199701)17:1<35::AIDJOC104>3.0.CO;2-F.

OECC, 2006: Plan nacional de adaptación al cambio climático, Oficina Española de Cambio Climático. Torreguil, España, p. $59 \mathrm{pp}$, available online: http://www.magrama.gob.es/es/cambio (last accessed on 15th March 2018).

Parker, D. E., 2011: Recent land surface air temperature trends assessed using the 20th Century Reanalysis, J. Geophys. Res., 116, doi:10.1029/2011JD016438.
Quereda, J., Ruescas, A., Monton, E., Escrig, J., and Mollá, B., 2004: Detection of the urban effect over temperature trend by means of NOAA-AVHRR Imagery, in: MeCeo, First Mediterranean Conference on Earth Observation, pp. 32-39.

Quereda, J., Montón, E., Quereda, V., and Mollá, B., 2016: Significant Climate Warming (1950-2013) in the Spanish Mediterranean: Natural Trend or Urban Heat Island (UHI), Tethys, 13, 11-20, doi:10.3369/tethys.2016.13.02.

Ren, G., Zhou, Y., Chu, Z., Zhou, J., Zhang, A., Guo, J., and Liu, X., 2008: Urbanization effects on observed surface air temperature trends in North China, J. Climate, 21, 1333-1348, doi:10.1175/2007JCLI1348.1.

Roberts, C. D., Palmer, M. D., McNeall, D., and Collins, M., 2015: Quantifying the likelihood of a continued hiatus in global warming, Nat. Clim. Change, 5, 337-342, doi:10.1038/nclimate2531.

Sachindra, D., Ng, A., Muthukumaran, S., and Perera, B., 2016: Impact of climate change on urban heat island effect and extreme temperatures: a case-study, Q. J. R. Meteorol. Soc, 142, 172186, doi:10.1002/qj.2642.

Solomon, S., Qin, D., Manning, M., Chen, Z., Marquis, M., Averyt, K. B., Tignor, M., and Miller, H. L., 2007: The physical science basis. Contribution of Working Group I to the Fourth Assessment Report of the Intergovernmental Panel on Climate Change, $\mathrm{p}$. 996 pp., available online: http://www.gcrio.org/online.html (last accessed on 15th March 2018).

Stocker, T. F., Qin, D., Plattner, G. K., Tignor, M., Allen, S. K., Boschung, J., Nauels, A., Xia, Y., Bex, V., and Midgley, P. M., 2013: The Physical Science Basis. Contribution of Working Group I to the Fifth Assessment Report of the Intergovernmental Panel on Climate Change, p. 1535 pp., available online: http://www.gcrio.org/online.html (last accessed on 15th March 2018).

Trenberth, K., Jones, P., Ambenje, P., Bojariu, R., Easterling, D., Tank, A. K., Parker, D., Rahimzadeh, F., Renwick, J., Rusticucci, M., et al., 2007: Observations: surface and atmospheric climate change. Chapter 3, Clim. Change, pp. 235-336, contribution of Working Group I to the Fourth Assessment Report of the Intergovernmental Panel on Climate Change. Available online: http://www.ipcc.ch/pdf/assessmentreport/ar4/wg1/ar4wg1-chapter3.pdf (last accessed on 15th March 2018).

Wrobel, J., 1940: Das Klima von Katalonien und der Provinz Castellón auf Grund der spanischen Wetterbeobachtungen der Jahre 1906 bis 1925, Hammerich \& Lesser.

Yan, Z., Li, Z., Li, Q., and Jones, P., 2010: Effects of site change and urbanisation in the Beijing temperature series 1977-2006, Int. J. Climatol., 30, 1226-1234, doi:10.1002/joc.1971. 